\title{
DEKONSTRUKSI PARADIGMA RADIKAL DALAM AL-QURAN
}

\author{
Lub Liyna Nabilata \\ Universitas Islam Negeri Sunan Kalijaga Yogyakarta, Indonesia \\ muaamalasadi17@gmail.com
}

\begin{abstract}
This paper aims to change the radical paradigm based on the verses of the Quran. Religion or verses of Quran often becomes a tool of legitimacy or justification of acts of violence. This research uses the methods of library research. From this research it is achieved that religious radicalism caused by the first war verses, often made up of legitimacy of violence and terrorism in Islam, the second, understanding the Jihad verses translated the war against the enemies of Islam, so that acts of violence against everything that was considered an enemy of Islam is the glorious Jihad
\end{abstract}

Keywords: radicalism, religion, violent ideological verses

\begin{abstract}
Abstrak
Tulisan ini bertujuan untuk merubah paradigma radikal berdasarkan ayat-ayat Al-Quran. Agama atau ayat-ayat al-Qur'an sering menjadi alat legitimasi atau pembenaran atas tindakan kekerasan. Penelitian ini menggunakan metode library research. Dari penelitian ini didapatkan bahwa muculnya radikalisme agama disebabkan oleh pertama, ayat-ayat perang sering dijadikan legitimasi atas prokekerasan dan aksi terorisme dalam Islam., kedua, memahami ayat-ayat Jihad diartikan perang melawan musuh Islam, sehingga tindakan kekerasan terhadap segala sesuatu yang dianggap musuh Islam merupakan Jihad yang mulia
\end{abstract}

Kata kunci: Radikalisme, Agama, Ayat-ayat Ideologi kekerasan

ISSN 2527-8401 (P) 2527-838X (e)

(C)2018 JISH Pascasarjana UIN Walisongo Semarang

http://journal.walisongo.ac.id/index.php/jish 


\section{Pendahuluan}

Gejala radikalisme Agama tidak pernah berhenti dalam rentang perjalanan sejarah umat Islam hingga sekarang. Bahkan, wacana tentang hubungan Agama (Islam) dan radikalisme belakangan semakin menguat seiring dengan munculnya berbagai tindakan kekerasan dan lahirnya gerakan-gerakan radikal. Sejumlah aksi radikal di Indonesia dalam beberapa dekade terakhir menunjukkan intensitas yang mengkhawatirkan. Kelompokkelompok radikal beraneka jubah memperkenalkan masing-masing back ground-nya, mulai dari yang berwajah etnis hingga agama. Dari sejumlah peristiwa, kolompok radikal agamalah yang memegang dominasi kekerasan tersebut.

Sejarah kekerasan dan radikalisme sering kali membawa nama Agama. Hal ini dapat dipahami karena Agama memiliki kekuatan yang dahsyat, yang melebihi kekuatan politik, sosial, dan budaya. Agama bahkan bisa diangkat sampai pada tingkat supranatural. Atas nama Agama, kemudian radikalisme diabsahkan dalam berbagai tindakan. Mulai dari mengkafirkan orang-orang yang tak sepaham (takfir) sampai melakukan pembunuhan terhadap musuh yang tidak seideologi dengannya.

Islam, yang sejatinya dari awal sejarah, memposisikan dirinya sebagai ummatan wasatan (umat yang moderat) dan sarat dengan nilai-nilai kedamaian serta gerakan moral dengan jargon advokasi kaum lemah. Sayangnya, nilai-nilai yang sedemikian ideal telah tereduksi oleh oknum yang memonopoli tafsir agama. Akibatnya agama dijadikan justifikasi atas tindakan kekerasan dan radikalisme. Agama telah dipenjara dan dieksploitasi sesuai dengan tendensi ideologis mereka. Walhasil, yang mencuat ke permukaan adalah truth claim (klaim kebenaran) dengan indikasi memunculkan sikap reaksioner-destruktif atas segala perbedaan (ikbtilaf).

Menurut Yusuf al-Qaradhawi, faktor utama munculnya radikalisme dalam beragama adalah kurangnya pemahaman yang benar dan mendalam atas esensi ajaran agama Islam itu sendiri dan pemahaman literalistik atas teks-teks agama. ${ }^{1}$ Menurut Arkoun, alQur'an telah digunakan muslim untuk mengabsahkan perilaku, menjustifikasi tindakan peperangan, melandasi berbagai apresiasi,

1 Yusuf Al-Qaradhawi, As-Sahwah Al-Islamiyyah Bayna Al-Jubud Wa atTatarruf (Kairo: Dar asy-Syuruq, 2001), 51-57. 
memelihara berbagai harapan, dan memperkukuh identitas kolektif. ${ }^{2}$

Pada kenyataannya, sebagian muslim yang melakukan tindakan kekerasan sering kali merujuk pada ayat al-Qur'an dan hadis Nabi saw yang dijadikan legitimasi dan dasar tindakannya. Padahal, Islam adalah agama universal dan moderat (wasatiyah) yang mengajarkan nilai-nilai toleransi (tasamub) yang menjadi salah satu ajaran inti Islam yang sejajar dengan ajaran lain, seperti keadilan ('ad), kasih sayang (rahmat), dan kebijaksanaan (hikmah). Sebagai rahmat bagi semesta alam, al-Qur'an mengakui kemajemukan keyakinan dan keberagamaan. Tetapi, sayang aksi dan tindakan kekerasan masih juga sering kali terjadi. Dan, sekali lagi, itu diabsahkan dengan dalil ayat-ayat al-Qur'an dan hadis Nabi saw.

Berangkat dari kegelisahan di atas, tulisan ini bermaksud menelah ayat-ayat al-Qur'an yang sering kali dijadikan landasan dan justifikasi radikalisme atas nama agama (Islam). Walaupun disadari bahwa faktor-faktor pemicu munculnya tindakan radikalisme beragama sangat kompleks dan beragam, namun ranah teologis dengan wilayah doktrin keagamaan dalam manusia sebagaimana diungkap oleh John L. Esposito bahwa kekerasan dan peperangan dalam agama senantiasa berangkat dari keimananan manusia. ${ }^{3}$ Ayat-ayat tersebut akan ditelaah sesuai dengan maknanya, aspek kesejarahannya (asbab an-nuzul) dan konteks sosialnya sehingga ditemukan ide moral dari ayat-ayat tersebut.

\section{Radikalisme dalam Al-Quran}

Secara bahasa, radikalisme berasal dari bahasa Latin, radix, yang berarti "akar". Ia adalah paham yang menghendaki adanya perubahan dan perombakan besar untuk mencapai kemajuan. Dalam perspektif ilmu sosial, radikalisme erat kaitannya dengan sikap atau posisi yang mendambakan perubahan terhadap status quo dengan cara menggantinya dengan sesuatu yang sama sekali baru

2 Mohammed Arkoun, Berbagai Pembacaan Al-Qur'an, terjh. Machasin (Jakarta: INIS, 1997), 9.

${ }^{3}$ John L. Esposito, Unholy War: Teror Atas Nama Islam (Yogyakarta: Ikon, 2003), 30. 
dan berbeda. ${ }^{4}$ Radikalisme merupakan respons terhadap kondisi yang sedang berlangsung yang muncul dalam bentuk evaluasi, penolakan, atau bahkan perlawanan terhadap ide, asumsi, kelembagaan, atau nilai.

Secara sederhana, radikalisme adalah pemikiran atau sikap yang ditandai oleh empat hal yang sekaligus menjadi karakteristiknya, yaitu: Pertama, sikap tidak toleran dan tidak mau menghargai pendapat atau keyakinan orang lain. Kedua, sikap fanatik, yakni sikap yang membenarkan diri sendiri dan menyalahkan orang lain. Ketiga, sikap eksklusif, yakni sikap tertutup dan berusaha berbeda dengan kebiasaan orang banyak. Keempat, sikap revolusioner, yakni kecenderungan untuk menggunakan kekerasan dalam mencapai tujuan.

Al-Qur'an mengecam keras sikap Ahli Kitab yang terlalu berlebihan dalam beragama sebagaimana firman Allah dalam Q.S. an-Nisa' [4]: 171 dan Q.S. al-Maidah [5]: 77. Sikap berlebihan itu pula yang membuat tatanan kehidupan umat terdahulu menjadi rusak sebagaimana disabdakan Nabi saw., "Wahai manusia, jaubilah sikap berlebiban (al-gulunw) dalam beragama. Sesunggubnya sikap berlebihan dalam beragama telah membinasakan umat sebelum kalian." (H.R. Ibnu Majah dan an-Nasa'i)

Menurut Azyumardi Azra, radikalisme merupakan bentuk ekstrem dari revivalisme. Revivalisme merupakan intensifikasi keislaman yang lebih berorientasi ke dalam (inward oriented), dengan artian pengaplikasian dari sebuah kepercayaan hanya diterapkan untuk diri pribadi. Adapun bentuk radikalisme yang cenderung berorientasi keluar (outward oriented), atau kadang dalam penerapannya cenderung menggunakan aksi kekerasan lazim disebut fundamentalisme. ${ }^{5}$

Dalam bahasa Arab, kekerasan dan radikalisme disebut dengan beberapa istilah, antara lain al-unf, at-tatarruf, al-guluww, dan al-irbab. Al-unf adalah antonim dari ar-rifg yang berarti lemah lembut dan kasih sayang. Abdullah an-Najjar mendefiniskan al-unf dengan penggunaan kekuatan secara ilegal (main hakim sendiri)

4 Edi Susanto, "Kemungkinan Munculnya Paham Islam Radikal Di Pesantren," Tadris 2, no. 1 (2007): 3.

${ }^{5}$ Azyumardi Azra, Islam Reformis: Dinamika Intelektual Dan Gerakan (Jakarta: Raja Grafindo Persada, 1999), 46-47. 
untuk memaksanakan kehendak dan pendapat. ${ }^{6}$ Kata at-tatarruf secara bahasa berasal dari kata at-tarf yang mengandung arti "ujung atau pinggir". Maksudnya berada di ujung atau pinggir, baik di ujung kiri maupun kanan. Karenanya, dalam bahasa Arab modern kata at-tatarruf berkonotasi makna radikal, ekstrem, dan berlebihan. ${ }^{7}$ Dengan demikian, at-tatarruf ad-dini berarti segala perbuatan yang berlebihan dalam beragama, yang merupakan lawan kata dari al-wasat (tengah/moderat) yang memiliki makna baik dan terpuji. Adapun kata al-guluww yang secara bahasa berarti berlebihan atau melampaui batas sering digunakan untuk menyebut praktik pengamalan agama yang ekstrem sehingga melebihi batas kewajaran

Dari penggunaan berbagai kata yang menunjuk radikalisme dan kekerasan dalam teks keagamaan (al-Qur'an dan hadis), terlihat dengan jelas bahwa pada prinsipnya Islam sangat menentang kekerasan dan radikalisme dalam berbagai bentuknya. Sebaliknya, sejak awal kemunculannya Islam telah memproklamirkan dirinya sebagai agama yang sarat dengan ajaran moderat (wasatiyah) yang senantiasa mengajarkan perdamaian, kedamaian, dan ko- eksistensi.

\section{Akar Sejarah Radikalisme Islam}

Sepanjang sejarah perjalanan Islam, banyak ditemukan fenomena pemasungan teks-teks keagamaan (al-Qur'an) untuk kepentingan politik yang ujung-ujungnya memicu tindakan radikalisme agama. Sebagai contoh peristiwa mihnah yang terjadi pada masa pemerintah khalifah al-Ma'mun (813-833 H). Dalam peristiwa tersebut, terjadi pemaksaan pendapat oleh golongan Mu'tazilah, sebuah golongan dalam Islam yang justru mengaku dirinya sebagai kelompok yang rasionalis. ${ }^{8}$ Tokoh-tokoh Islam dan pemuka masyarakat yang tidak sependapat dengan sekte tersebut dipenjarakan, disiksa dan bahkan ada yang dihukum mati. Ironisnya, fenomena radikalisme agama semacam ini tidak pernah

${ }^{6}$ Kementerian Agama, Tafsir Al-Qur'an Tematik (Jakarta: Kamil Pustaka, 2014), 97.

7 Muchlis M. Hanafi, “Konsep Al-Wasathiyyah Dalam Islam," Harmoni 8, no. 32 (2009): 39 .

${ }^{8}$ Philip K. Hitti, History of The Arabs, Tenth (London: The Macmilan Press LTD, 1974), 181-83. 
berhenti dalam rentang perjalanan sejarah umat Islam hingga sekarang.

Gerakan kaum Khawarij yang muncul pada masa akhir pemerintahan Ali ibn Abi Talib dengan prinsip-prinsip radikal dan ekstrim dapat dilihat sebagai gerakan fundamentalisme klasik dalam sejarah Islam. Langkah radikal mereka diabsahkan dengan semboyan la bukma illa lilllah (tidak ada hukum kecuali milik Allah) dan la hakama illa Allah (tidak ada hakim selain Allah) yang dielaborasi berdasar Q.S. al-Ma'idah: 44 yang berbunyi: wa man lam yabkum bima anzala Allabu fa ulaika hum al-kafirun (siapa yang tidak menentukan hukum dengan apa yang diturunkan Allah, maka mereka adalah kafir). Karena alasan demikian, kelompok Khawarij tidak mau tunduk kepada Ali dan Mu'awiyah.'

Dari rekaman sejarah tersebut bisa dilihat bahwa fundamentalisme Islam lebih banyak menekankan atau setidaknya membenarkan penggunaan kekerasan atas nama agama. Islam dianggap mengajarkan para pemeluknya yang fanatik untuk melakukan tindakan kekerasan tersebut sebagai manifestasi dari keimanan. Dari peristiwa semacam itulah, kemudian ada sebagian orang yang membayangkan adanya sekelompok umat Islam yang meyakini bahwa Tuhan telah menyuruhnya untuk melakukan segala tindakan untuk membela agamanya meskipun salah sekalipun. Pandangan teologis radikal tersebut diikuti oleh sikap politik yang ekstrim dan radikal pula. Mereka berpandangan bahwa orang-orang yang tidak sependapat dengan mereka dianggap musyrik dan boleh dibunuh. Karena itu, hanya kawasan mereka yang disebut dar al-Islam yang harus dilindungi sedangkan kawasan lain adalah dar al-kuffar yang harus diperangi dan dihancurkan.

Pada masa pra-modern, gerakan fundamentalisme radikal muncul di semenanjung Arabia di bawah pimpinan Muhammad ibn 'Abd al-Wahhab (1703-1792). Dengan mengusung tema memurnikan Islam, gerakan ini melakukan tindak kekerasan dengan membunuh orang-orang yang dianggap bid'ah, tahayul dan khurafat dan menghancurkan monumen-monumen historis di Mekah dan Madinah.

9 Azyumardi Azra, Pergolakan Politik Islam (Bandung: Mizan, 1999), 112113. 
Dengan demikian nampak fundamentalisme radikal klasik dan pra modern sangat dipengaruhi landasan teologi fundamental yang didasari semangat kebangkitan Islam (revivalisme of Islam). Sedangkan gerakan fundamentalisme radikal dalam Islam dewasa ini, lebih banyak dipengaruhi respon Islam atas Barat, meskipun tema-tema yang berkaitan dengan inward oriented tetap menjadi concern dan pilihan ideologis mereka. Paling tidak ada dua masalah besar yang menjadi perhatian kelompok ini. Pertama, mereka menolak sekularisme masyarakat Barat yag memisahkan agama dari politik, gereja dari negara. Kesuksesan Barat melakukan sekularisasi dianggap sebagai sesuatu yang berbahaya karena dapat mengancam Islam sebagai agama yang tidak hanya mengurusi persoalan ukhrawi saja, tetapi sekaligus duniawi. Kedua, banyak umat Islam yang menginginkan agar masyarakat mereka diperintahkan dengan menggunakan al-Qur'an dan syari'at Islam sebagai aturan bernegara. ${ }^{10}$

Tidak mengherankan jika dewasa ini muncul gerakan-gerakan bawah tanah yang bercita-cita membangun kbilafah Islamiyyah dan diiringi dengan tema-tema kedaulatan tuhan (bakimiyyat Allab), jihad, revolusi Islam, keadilan sosial dan sebagainya. Tema-tema tersebut diorientasikan pada masa lampau, khususnya generasi awal Islam sebagaimana yang dipraktikkan Rasulullah dan para sahabat. Karena mereka menganggap bahwa masyarakat Islam sekarang mengalami kemunduran semakin jauh dari praktik Islam. Karenanya agenda-agenda di atas harus dilakukan untuk melawan hegemoni Barat sambil membayangkan romantisme sejarah kejayaan Islam agar terwujud di zaman modern. ${ }^{11}$

Dari paparan historis di atas, dapat dikatakan bahwa radikalisme dan fundamentalisme Islam, sebagaimana juga fundamentalisme dalam agama lain, memiliki beberapa karakteristik yang membedakannya dengan kelompok lain. Pertama, skripturalisme, yaitu pemahaman harfiah dan tektualis atas ayatayat al-Qur'an. Karenanya mereka menolak hermeneutika sebagai cara dalam memahami al-Qur'an. Kedua, penolakan terhadap

${ }^{10}$ Karen Armstrong, Berperang Demi Tuhan, Fundamentalisme Dalam Islam, Kristen Dan Yabudi (Jakarta: Serambi, 2001), ix.

11 Leonard Binder, Islamic Liberalism; A Critique of Development Ideologies (Chicago and London: The University of Chicago Press, 1988), 16-19. 
pluralisme dan relativisme yang dianggap akan merusak kesucian teks. Ketiga, penolakan terhadap pendekatan historis dan sosiologis yang dipandang akan membawa manusia melenceng jauh dari doktrin literal kitab suci. Keempat, memonopoli kebenaran atas tafsir agama, di mana mereka menganggap dirinya yang paling berwenang dalam menafsirkan kitab suci dan memandang yang lainnya sebagai kelompok yang sesat. ${ }^{12}$

Ketika teks-teks keagamaan dipahami secara dangkal, maka tidak menutup kemungkinan akan melahirkan paham dan gerakan radikal. Karena itulah, untuk menangkal gerakan radikal, salah satu langkah yang diperlukan adalah pemahaman yang benar dan komprehensif atas teks-teks keagamaan tersebut. Inilah yang akan dijelaskan dalam paragraf-paragraf berikut ini.

\section{Relasi antara Agama dan Radikalisme}

Jika membaca secara teliti peristiwa-peristiwa besar kekerasan yang disebabkan oleh agama, ditemukan paling tidak ada tiga peran yang menyebabkan kerentanan agama terhadap kekerasan. ${ }^{13}$ Pertama, adanya penafsiran agama dalam hubungannya dengan relasi sosial. Tafsiran ini selanjutnya menjadi dasar ideologis dari pemeluk agama dalam ruang sosial. Yakni, tatanan sosial ditafsirkan sedemikian sehingga berdasarkan kerangka religius tertentu. Tatanan masyarakat direpresentasikan sebagai kehendak Tuhan berdasakan hasil tafsirannya sendiri terhadap teks suci. Diversitas realitas diunifikasi dan disimplifikasi menjadi suatu realitas yang seragam. Identitas-identitas subjek yang unik akhirnya hilang dalam suatu kerangka pemahaman (tafsir) yang "sempit". Sebab, realitas yang kompleks dan jamak diarahkan pada kehendak kelompok tertentu. Di sinilah, keberadaan orang atau kelompok lain mulai dinafikan. Bahkan, jika umat beragama tidak mau mengubah pemahaman yang diyakini sebagai "kebenaran mutlak", maka agama mandul, nyaris tak bermakna. ${ }^{14}$ Selain itu, tafsiran ini juga memiliki kecenderungan menyembunyikan kepentingan pribadi dan kelompok tertentu. ${ }^{15}$

12 Hans Kung and Jurgen Moltmann, Fundamentalism as a Ecumanical Challenge (London: Mac Millan, 1992), 3-13.

${ }^{13}$ Haryatmoko, Etika Politik Dan Kekuasaan (Jakarta: Kompas, 2003), 64.

${ }^{14}$ Zuly Qodir, Radikalisme Agama Di Indonesia (Yogyakarta: Pustaka Pelajar, 2014), 55.

15 Penyembunyian ini menurut Haryatmoko, terkait dengan peran ideologis agama, dalam arti sebagai faktor integrasi dan pembenaran dominasi. Apa yang 
Kedua, terbentuknya identitas kolektif keagamaan yang terintegrasi dengan identitas etnik. ${ }^{16}$ Pengidentifikasian ini membawa pada sikap yang fanatik, karena pada saat yang sama memiliki dua alasan sekaligus. Rawannya, masyarakat yang mengidentifikasi diri dalam salah satu kelompok ini sulit menerima keberadaan orang lain. Orang lain (di luar kelompoknya) selalu dipandang sebagai yang lain. Bahkan, mereka telah melabelkan predikat tertentu kepada orang lain berdasarkan pikirannya sendiri, bukan sebagaimana yang dipikirkan oleh orang (lain) itu sendiri. Pada akhirnya, yang terjadi adalah stigmatisasi dan stereotiping. Orang lain dibentuk dan citrakan sebagai masyarakat yang lebih rendah, kumuh, kurang beradab, kasar, dan lain-lain bahkan dianggap tidak berperadaban. Ini terjadi tidak pada satu pihak saja, tetapi juga pada pihak lainnya. Pada tingkat yang lebih ekstrim, kelompok etnis dan agama yang berbeda dengannya dipandang sebagai "setengah manusia". Akibatnya, ketika mereka membunuh salah satu dari mereka pun tidak diangggap sebagai suatu beban atau kesalahan, tetapi sebagai sesuatu yang biasa-biasa saja bahkan dianggap sebagai bagian dari 'ibadah'.

Ketiga, semakin kuatnya legitimasi moral dalam tatanan sosial, berbeda dengan yang pertama, yang melihat tatanan sosial dalam kerangka tafsir teologis, pada bagian ini agama dilegitimasi dan direpresentasikan dalam suatu nilai yang sudah penuh. Mereka merasa tidak memerlukan lagi perangkat nilai lain yang datang dari luar, seperti egaliter, kemanusiaan, keadilan dan lain-lain. Nilai-nilai seperti ini dipandangnya sebagai sesuatu yang baru, sehingga ditolak dan dipandang sebagai produk Barat yang kafir. Islam dipahami, bahkan sebagai agama yang tidak memiliki keterkaitan dengan tradisi lain.

Barat sering dipertentangkan dengan Islam. Pada kasus Islam dan demokrasi misalnya, ada setidaknya tiga kelompok besar yang selalu mengitari isu ini. Ada kelompok yang menamakan diri rejeksionis yang dengan terbuka menolak demokrasi dengan alasan

ditafsirkan dan mendapat pembenaran dari agama adalah hubungan kekuasaan karena setiap tindakan dan setiap kekuasaan selalu mencari legitimasi.

16 Ini dapat dilihat misalnya pada pengidentifikasian masyarakat Aceh sebagai masyarakat Muslim dan Batak adalah Kristen, Bugis Islam dan Toraja Kristen, Nusa Tenggara Barat Muslim dan Nusa Tenggara Timur Kristen, dan lain-lain. 
ia adalah produk Barat. Ada pula yang menggolongkan diri sebagai kelompok menerima demokrasi. Juga ada kelompok apologetis yang melihat bahwa demokrasi juga di dalamnya terdapat nilai-nilai Islam, artinya sangat islami. Sebab, baginya Islam sangat menjunjung tinggi nilai-nilai persamaan, keadilan, dan lain-lain sebagaimana demokrasi. Kelompok terakhir adalah kelompok yang selalu memposisikan diri pada titik aman, tidak memihak secara jelas pada dua kelompok tadi.

Dari penjelasan di atas maka semakin jelaslah mudus-modus operandi kekerasan atas nama agama. Agama yang sejatinya diinternalisasi dan direfleksikan menjadi nilai utama kehidupan pada akhirnya menjadi kehilangan makna dan fungsinya. Agama tidak lagi mengajarkan kasih sayang, tetapi justru menawarkan kekejaman dan kedengkian. Fungsi agama pun beralih menjadi fungsi pragmatis dan hanya digunakan oleh sekelompok orang yang memiliki obsesi berlebihan dalam mencapai hasratnya. Fungsi agama sebagai rahmat (Islam) tidak lagi tercermin dan terefleksikan dalam tutur dan tindakan, ia justru diseret mengikuti kepentingan yang bersifat pragmatis-oportunis. Hukum agama tidak lagi memihak pada kebenaran yang mengedepankan penghargaan terhadap harkat dan martabat kemanusiaan, menjunjung tinggi keadilan, kesetaraan dan spirit positif lainnya, hukum bahkan justru memihak kepada siapa yang memiliki kekuatan yang digunakan untuk menindas yang lemah, minoritas, dan kelompok-kelompok termarginalkan lainnya. Baik agama maupun hukum muncul dengan wajah menyeramkan, yang jauh dari konteks dasarnya yang berisi misi kedamaian dan anti terhadap kekerasan.

\section{Radikalisme Sebagai Pilihan Sebuah Metode}

Radikalisme, khususnya radikalisme Islam muncul sebagai respons terhadap kondisi memprihatinkan yang dialami dan dihadapi umat. Persoalan ketimpangan, ketidakadilan, dan diskriminasi terjadi di mana-mana yang memantik aksi sekelompok orang melakukan berbagai upaya dalam rangka melakukan perlawanan terhadap kondisi-kondisi tersebut. Umumnya, pilihan tindakan yang diambil adalah jalur kekerasan karena jalur lain dianggap tidak 'mempan' lagi. Di dunia Islam, misalnya di Timur Tengah, radikalisme Islam muncul sebagai perlawanan kontra- 
produktif terhadap perlakuan tidak adil atau penyumbatan aspirasi politik oleh rezim otoriter. ${ }^{17}$

Bagi Mun'in A Sirry, menguatnya radikalisme Islam merupakan fenomena modern. Mereka yang tergabung dalam kelompok ini berasal dari intelektual perkotaan, artinya berasal dari kalangan masyarakat moderen (modernis). Bagi mereka, apa yang dipilih merupakan cara untuk melawan unfairness yang dapat mewujud dalam bentuk modernisasi termasuk produk-produknya. Dalam konteks Indonesia, fenomena radikalisme bahkan fundamentalisme juga marak dan terus mendapat respons dari penentangnya. Radikalisme Islam direspons oleh moderasi Islam yang mengusung ide keterbukaan dan kesetaraan. Sementara itu, fundamentalisme dilawam dengan mempromosikan demokrasi yang dianggap telah menemukan tempatnya di Indonesia. Indonesia terkait dengan hal demokrasi dinilai berhasil karena kedaulatan telah berada di tangan rakyat. ${ }^{18}$

Tindakan radikal dipicu oleh salah satunya adalah, kekurangpuasan terhadap kondisi yang sedang terjadi. Ada sikap yang tidak bisa lagi dibendung karena telah terjadi dan terus berulang tanpa diiringi oleh upaya nyata (oleh negara) untuk menyelesaikannya. Hal ini pun kemudian direspons dengan berbagai bentuk tindakan (kekerasan) yang diikuti oleh pelibatan teks kitab suci (Al Qur'an) sebagai alat pengesah tindakan. Jika dirunut lebih jauh ke belakang, pemahaman akibat penafiran yang sempit terhadap teks kitab suci menjadi pemicu utama munculnya paham radikal. Paham radikal sesungguhnya menjadi fenomena biasa. Sebab, dalam tradisi agama mana pun di luar Islam, fenomena ini dapat ditemukan dengan berbagai varian dan dinamikanya.

Pemahaman yang sempit terhadap Islam yang lahir dari interpretasi yang bersifat parsial terhadap teks membentuk pola pikir yang sangat kaku. Bahkan, apa yang dipahami (mereka) adalah satu-satunya kebenaran dan akibatnya menafikan kebenaran dan keberadaan orang atau kelompok lain. Islam pun kemudian dijadikan legitimasi atas tindakan 'barbar' yang dilakukan. Kasus

17 Mun'in A Sirry, Membendung Militansi Agama: Iman Dan Politik Dalam Masyarakat Modern (Jakarta: Erlangga, 2003), 36.

18 Mun'im A. Sirry, Membendung Militansi Agama (Jakarta: Erlangga, 2003), 37. 
bom di Bali misalnya, menjadi contoh penting untuk dijadikan acuan dalam menilai bagaimana hasrat kelompok tertentu berusaha menghilangkan orang lain dengan dalih agama. Bagi para pelakuknya, mati dalam melaksanakan dan setelah aksi tersebut adalah syahid, dan ganjarannya adalah syurga. Dari simpulan singkat ini dapat dilihat bahwa ada upaya menyederhanakan penafsiran sebuah dalil (ayat) sehingga seakan-akan tindakan yang dilakukan seperti pengeboman di tempat-tempat umum sah atau legal dilakukan karena ada justifikasinya dalam agama (Islam).

Tentu saja, tindakan radikal yang diawali oleh paham radikal seperti yang telah terjadi di Indonesia tidak berdiri sendiri. Konteks nasional ini tidak lepas dari konteks global. Kasus 11 September beberapa tahun lalu sangat memojokkan Islam. Hal ini pun direspons oleh kelompok-kelompok Islam di berbagai negara di dunia dengan segala bentuk aksi dan tindakan yang frontal. Hal ini juga dapat dipahami sebagai bentuk pembelaan sekaligus menunjukkan kelemahan agama. Agama cenderung pada kekerasan ketika identitasnya terancam. ${ }^{19}$

Di Indonesia sendiri, radikalisme yang diwarnai oleh agama sesungguhnya bukan barang baru, khususnya terkait dengan kelompok radikal Islam. Dalam sejarah Indonesia dikenal beberapa perang misalnya Perang Padri di Sumatera Barat antara kaum ulama puritan dengan kelompok adat yang juga penganut Islam namun bukan puritan. Kaum Padri ini dikenal sebagai penganut Wahabi yang bertujuan melakukan pemurnian ajaran Islam yang diklaim telah meyimpang dari ajaran dasarnya. Hanya saja, gerakan ini diikuti oleh kekerasan sehingga terjadi pertumpahan darah di Minangkabau kala itu. Gerakan radikal Islam inilah, menurut AS Hikam, muncul kembali walaupun dalam konteks yang berbeda namun disertai dengan gagasan dan pemahaman keagamaan yang tidak jauh berbeda. ${ }^{20}$

\section{Analisis Atas Ayat-Ayat Kekerasan}

${ }_{19}$ Wim Beuken and Karl-Josef Kuschel, Agama Sebagai Sumber Kekerasan? (Pustaka Pelajar, 2003), 141.

20 Muhammad AS Hikam, Peran Masyarakat Sipil Indonesia Membendung Radikalisme (Jakarta: Kompas, 2016), 34. 
Ayat-ayat al-Qur'an yang sering kali disalahpahami dan dijadikan dalil bagi tindakan-tindakan radikal adalah ayat-ayat jihad dan ayat-ayat perang. Karena itu, menjadi penting untuk memahami ayat-ayat tersebut sesuai dengan konteks dan maksud pensyariatannya. Berikut ini akan diuraikan tentang kedua kelompok ayat tersebut.

1. Ayat-ayat perang. Ayat-ayat yang kerap kali dijadikan dasar pengembangan stereotype untuk mengidentifikasi Islam sebagai agama pro-kekerasan dan mendukung aksi terorisme adalah ayat-ayat perang. Karena itu, dalam paparan berikut ini ayat-ayat tersebut akan dikaji sesuai dengan konteks dan maknanya dalam perspektif Al-Qur'an.

Kata qital (perang) dengan berbagai bentuknya disebut dalam alQur'an sebanyak 12 kali. Secara bahasa, qital berasal dari qa-ta-la yang membentuk kata benda, al-qatl yang bermakna melenyapkan ruh atau kehidupan dari tubuh seseorang.

Q.S. al-Hajj [22]: 39-40 adalah ayat pertama kali yang turun terkait dengan perintah perang dalam Islam, setelah selama lebih dari sepuluh tahun di Mekah, kaum muslim dianiaya. Sebelum diizinkan untuk berperang, mereka diperintahkan untuk menahan diri (Q.S. an-Nisa' [4]: 77) dan tetap bersabar dan berteguh hati (Q.S. al-Baqarah [2]: 109; Q.S. al-Ankabut [29]: 59, dan Q.S. an-Nahl [16]: 42). Setelah kaum muslim terusir dari kampung halaman mereka dan orang-orang yang tetap tinggal bahkan mengalami perlakuan yang lebih kejam, barulah Allah mengizinkan mereka untuk berperang.

Akan tetapi, sebagaimana dikemukakan Syalabi, siapa yang mendalami ayat tersebut akan melihat bahwa Islam sebenarnya tidaklah menginginkan peperangan. Ini bisa dilihat dari penggunaan kata kerja pada awal ayat yang menggunakan term mabniy majbul (uzina) di mana pelaku ( a $^{\prime} i$ )-nya yang dalam hal ini Allah disembunyikan. Ini menggambarkan betapa Allah tidak senang dengan peperangan. Secara fitrah, memang manusia cenderung tidak menyukai perang dan kekerasan (Q.S. al-Baqarah [2]: 216). Karenanya, ketika ayat ini turun, ada kaum 
muslim ada yang belum cukup yakin dengan ayat ini untuk dijadikan alasan untuk melakukan peperangan. ${ }^{21}$

Dari sini, maka hubungan Islam dengan dunia luar dibangun atas dasar perdamaian. Namun, dalam kondisi tertentu, seperti ada pihak yang memerangi Islam dan mengganggu agama, maka perang pun kemudian dibenarkan. Bahkan, perang dalam rangka membela agama bukan hanya dibenarkan oleh Islam.

Setelah ayat tersebut, kemudian Allah menurunkan ayat yang menegaskan tentang diperbolehkannya perang sebagai penguat ayat di atas, yakni Q.S. al-Baqarah [2]: 190 "dan perangilah di jalan Allah orang-orang yang memerangi kamu, (tetapi) janganlah kamu melampaui batas, karena sesungguhnya Allah tidak menyukai orangorang yang melampaui batas”. Pemberian izin perang dalam ayat ini tidaklah mutlak, melainkan bersyarat bahwa peperangan itu dilakukan kepada orang yang memerangi saja dan tidak melampaui batas. Nabi saw. dan para penerusnya, ketika mengirimkan pasukan perang, selalu memberikan intruksi agar tidak menyerang penduduk sipil, yakni kaum wanita, orang tua, dan umat beragama yang sedang beribadah, atau memusnahkan hasil panen dan ternak mereka. Artinya, Islam melihat peperangan lebih sebagai tindakan defensif. Ofensif hanya dipandang legitimate untuk membela kebebasan beragama (Q.S. al-Hajj [22]: 39-41), melawan penyerangan dan membela diri (Q.S. al-Baqarah [2]: 190), membela orang-orang yang tertindas atas penindasan kelompok lain, ${ }^{22}$ pengkhianatan terhadap perjanjian, dan penganiayaan (fitnah) sebagaimana dijelaskan ayat-ayat yang lalu dan ayat-ayat ini: Q.S. an-Nisa' [4]: 75, Q.S. al-Baqarah [2]: 251, Q.S. al-Anfal [8]:55-57, Q.S. al-Anfal [8]: 39, dan Q.S. al-Baqarah [2]:191-193.

Jika Q.S. al-Anfal [8]: 190 berbicara tentang kapan peperangan diizinkan untuk dimulai oleh kaum muslim, maka ayat 193 menjelaskan kapan peperangan harus mereka hentikan serta konsekuensi yang dipikul oleh yang enggan menghentikannya. Ia dapat dimulai saat ada musuh yang menyerang. Mereka itulah

21 A. Syalabi, Sejarah Dan Kebudayaan Islam (Jakarta: Pustaka al-Husna, 1994), 154.

22 Abbas Mahmud Al-Aqqad, Haqaiq Al-Islam Wa Abatil Khusumih (Kairo: Mu'assasah Hindawi, 2013), 149-151. 
yang diperangi sedang peperangan harus dihentikan bukan saat agama Islam tersebar ke seluruh dunia, tetapi ia harus dihentikan saat penganiayaan berakhir, karena tujuan peperangan adalah menghentikan penganiayaan.

Begitu pentingnya penghentian peperangan dan keinginan alQur'an untuk mencipatakan perdamaian, sampai Allah mengingatkan dalam Q.S. al-Anfal [8]: 61. Ketika perang selesai pun, al-Qur'an ataupun hadis memberikan berbagai ketentuan menyangkut perlakuan terhadap tawanan perang dan hubungan baru dengan kaum non-muslim. Perang tentu saja tidak dilihat sebagai alat dalam agama untuk mengubah agama masyarakat lain. ${ }^{23}$ Jadi, dalam perang sekalipun, al-Qur'an mengaitkan perintah berperang dengan perintah agar tidak melampaui batas, siap memaafkan, dan mendahulukan perdamaian. Balasan atas kezaliman pihak lain diingatkan al-Qur'an agar dengan cara yang setimpal dan mengembalikan situasi kepada keadaan yang normal (seimbang), sebagaimana firman Allah Q.S. an-Nahl [16]: 16.

Ayat tersebut turun terkait dengan kemarahan Rasulullah saw atas kematian pamannya, Hamzah bin Abdul Muthalib, yang sangat mengenaskan dan diperlakukan secara tidak manusiawi dalam Perang Uhud. Melihat hal itu, kaum muslim bermaksud membunuh 70 orang Mekah sebagai ganti nyawa mereka. Karena itu, jika menelaah teks-teks keagamaan dan sejarah peperangan dalam Islam, Islam memberikan sejumlah etika dalam peperangan yang sejalan dengan prinsip-prinsip kemanusiaan.

Syekh Ali Jumu'ah, Mufti Agung Mesir, menyebutkan enam syarat dan etika perang dalam Islam yang membedakannya dengan terorisme, yakni: cara dan tujuannya jelas dan mulia; perang hanya dibolehkan terhadap pasukan yang memerangi, bukan penduduk sipil; perang harus dihentikan bila pihak lawan telah menyerah dan memilih perdamaian; melindungi tawanan perang dan memperlakukannya secara manusiawi; memelihara lingkungan, antara lain tidak membunuh binatang tanpa alasan,

23 Muhammad Abdul Halim, Menafsirkan Al-Qur'an Dengan Metode Menafsirkan Al- Qur'an Dengan Al-Qur'an, terjh. Rofik Suhud (Bandung: Marja, 2012), 97. 
membakar pohon, merusak tanaman, mencemari air dan sumur, dan merusak rumah atau bangunan; dan menjaga hak kebebasan beragama para agamawan dan pendeta dengan tidak melukai mereka. ${ }^{24}$

2. Ayat-ayat jihad. Bagi sebagian kelompok, jihad terkadang diartikan perang melawan musuh Islam, sehingga tindakan kekerasan terhadap segala sesuatu yang dianggap musuh Islam, merupakan perbuatan jihad yang mulia. Akibatnya, kata jihad menjadi sesuatu yang mengerikan dan mengakibatkan Islam menjadi tertuduh. Islam dipandang oleh orang di luar Islam dan Barat sebagai agama teroris. Sehingga, tidak berlebihan jika dikatakan bahwa istilah jihad merupakan salah satu konsepsi Islam yang paling sering disalahpahami, khususnya di kalangan para ahli dan pengamat Barat. Padahal, jika di telusuri kata jihad dalam al-Qur'an berbeda dengan radikalisme dan peperangan. Jihad selain merupakan salah satu inti ajaran Islam, juga tidak bisa disederhanakan dan diindentikkan dengan perang (qital). ${ }^{25}$ Sebagai doktrin agama, jihad merupakan amunisi doktrinal yang berfungsi sebagai alat perjuangan agama dalam menjawab tantangan zaman. Hal yang perlu disadari adalah bahwa jihad bukanlah produk otoritas individu atau penafsiran organisasi tertentu. Melainkan produk dari berbagai individu dan otoritas yang menafsirkan dan menerapkan prinsip-prinsip teks-teks suci dalam konteks-konteks khusus secara historis dan politis. Untuk itu kita harus membaca dan memahami ayat-ayat al-Qur'an secara historis. Kita bisa melihat ayat-ayat al-Qur'an yang membahas tentang jihad dalam Q.S. 29: 69 yang artinya: "Dan mereka yang berjuang di jalan Kami, dan sesunggubnya Tuban bersama mereka yang berbuat kebaikan" dan terdapat juga dalam Q.S. 22:78 yang artinya: "Dan berjuanglah untuk. Allab dengan sungguh-sungguh" serta dalam Q.S. 2: 190 yang artinya: "Dan perangilah di jalan Allah orang-orang yang memerangi kamu, (tetapi) janganlah kamu

24 Ali Jumu'ah, Haqiqat Al-Islam Fi 'Alam Mutagayyir (Kairo: Kementerian Wakaf Mesir, 2003), 700.

25 Abd. A'la, "Pembumian Jihad Dalam Konteks Indonesia Kekinian: Pengentasan Masyarakat Dari Kemiskinan Dan Keterbelakangan," Harmoni 8, no. 32 (2009): 55 . 
melampaui batas, karena sesunggubnya Allah tidak menyukai orangorang yang melampaui batas".

Kandungan ayat-ayat di atas menekankan jihad sebagai perjuangan yang inhern dengan kesulitan dan kerumitan menuju kehidupan yang lebih baik. Berjuang melawan hawa nafsu di dalam diri sendiri dalam rangka mencapai keutamaan, melakukan upaya sungguh-sungguh untuk berbuat kebajikan dan membantu memperbaiki kehidupan masyarakat.

Pandangan Asghar Ali Engginer tentang konsep Jihad dalam Islam yaitu yang tidak identik dengan kekerasan dan radikalisme. Distorsi makna jihad tanpaknya telah dilakukan oleh Ellian Antoon dalam kamusnya yang memaknai jihad sama dengan perang suci atas nama agama. Padahal jika ditelusuri lebih dalam kata "jihad" yang berasal dari kata jabada dan berbagai derivasinya tidak ada satupun yang menjelaskan bahwa jihad erat dengan radikalisme atau peperangan. ${ }^{26}$

Sebagaimana kata jihad yang terdapat dalam surat al-Taubah ayat 24 yang artinya: "katakanlah, jika bapak-bapakmu, anakanakmu, saudara-saudaramu, isteri-isterimu, keluargamu, harta kekayaan yang kamu usabakan, perdagangan yang kamu khawatirkan kerugiannya, dan rumah-rumah tempat tinggal yang kamu sukai, lebih kamu cintai dari pada Allah dan Rasul-Nya serta berjibad di jalan-Nya, maka tunggulah sampai Allah memberi keputusan. Dan Allah tidak. memberi petunjuk orang-orang yang fasik."

Kata jihad juga terdapat dalam surat al-Hajj ayat 78 yang artinya: "Dan berjibad lah kamu di jalan Allah dengan jihad yang sebenarbenarnya. Dia telah memilib kamu dan Dia telah menjadikakan kesukaran untukmu dalam agama, ikutilah agama nenek moyangmu Ibrabim"

Selanjutnya kata jihad juga ditemukan dalam surat alMumtahanah ayat 1 yang artinya : "jika kamu benar-benar keluar untuk beriihad pada jalan-Ku dan mencari keridlaan-Ku (janganlah kamu berbuat demikian) kamu memberitabukan secara rahasia (beritaberita Muhammad) kepada mereka, karena rasa kasih sayang dan Aku lebih mengetahui apa yang kamu sembunyikan dan apa yang kamu nyatakan.."

26 Asghar Ali Engineer, "Islam and Doctrines of Peace and NonViolence," Ibya 'Ulumuddin 3 (2001): 121. 
Kata jihad juga dapat ditemukan dalam surat al-Taubah ayat 19 yang artinya : "apakah (orang-orang) yang memberi minuman kepada orang-orang yang mengerjakan haji dan mengurus Masjid al Haram kamu samakan dengan orang yang beriman kepada Allah dan hari kemudian serta berjibad di jalan Allah? Mereka tidak sama di sisi Allah. Allah tidak memberikan petunjuk kepada orang-orang yang zalim".

Dalam surat al-Hujarat ayat 1 juga jihad ditemukan yang artinya: "sesunggubnya orang-orang yang sebenarny a adalah mereka yang beriman kepada Allah dan Rasul-Nya, kemudian mereka tidak ragu-ragu dan mereka berjihad dengan harta dan jiwwanya di jalan Allah. Mereka itulah orang-orang yang benar."

Kata jihad juga muncul dalam surat al-'Ankabut ayat 6 yang artinya : "Dan barang siapa berjihad, maka sesunggubnya jihadnya untuk dirinya. Sunggub Allah Maha Kaya dari selurub alam.

Secara umum, al-Qur'an menjelaskan jihad dalam konteks pembahasan yang beragam, namun semuanya menjelaskan bahwa jihad menurut al-Qur'an adalah perjuangan untuk mewujudkan as-salam, as-salamah, al-salah, dan al-ibsan, yakni perjuangan untuk mewujudkan perdamaian, kesejahteraan, dan perbaikan kualitas hidup sesuai ajaran al-Qur'an. Perjuangan untuk mewujudkan itu semua disebut jihad fi sabilillah (perjuangan di jalan Allah). ${ }^{27}$ Dalam Q.S. al-Ma'idah [5]: 35, perjuangan mewujudkan kesejahteraan hidup lahir-batin dan dunia-akhirat merupakan kewajiban setiap orang beriman yang harus dilakukan atas dasar ketakwaan kepada Allah dan usaha (ikhtiar) orang beriman sebagai khalifah Allah di muka bumi untuk mengubah keadaan agar lebih baik dan lebih berkualitas lahir batin guna mendapatkan al-falah, keberuntungan dunia dan akhirat.

Jihad di jalan Allah juga harus diawali dengan hijrah, yakni mengubah pikiran, keyakinan, emosi, persepsi, sikap, dan perilaku yang tidak sesuai dengan pesan al-Qur'an. Jadi, hijrah merupakan prakondisi yang diperlukan untuk bisa melaksanakan perintah berjihad, setelah seseorang beriman dan bertakwa. Oleh sebab itu, dalam banyak ayat al-Qur'an, Allah meletakkan hijrah setelah beriman dan sebelum berjihad,

${ }^{27}$ Kementerian Agama, Tafsir Al-Qur'an Tematik, 82-83. 
sebagaimana terdapat dalam Q.S. al-Baqarah [2]: 218 dan Q.S. al-Anfal [8]: 74.

Al-Qur'an menegaskan dua cara untuk melaksanakan jihad di jalan Allah, yakni dengan harta (mal, amwal) dan jiwa (nafs, anfus) sebagaimana dinyatakan dalam Q.S. an-Nisa [4]: 95; Q.S. alAnfal [8]: 72; Q.S. at-Taubah [9]: 20, 44, 81, 88; Q.S. al-Hujurat [49]: 15; dan Q.S. ash-Shaff [61]: 11. Berbagai tujuan jihad sebagaimana telah dijelaskan sebelumnya tidak akan tercapai tanpa kesediaan untuk mengorbankan harta, sebab harta merupakan penopang utama jihad di jalan Allah. Jihad dengan harta bisa disalurkan melalui wakaf, infak, sedekah, ataupun program penggalangan dana untuk berbagai kepentingan umat. Keluasan makna jihad sebagaimana ditunjukkan ayat-ayat alQur'an di atas inilah yang menjadikan ajaran Islam sebagai powerful symbol bagi ketekunan, kerja keras, dan keberhasilan dalam sejarah Islam. Jihadlah yang mengantarkan kaum muslim menjadi khalifah Allah yang mengisi semua aspek kehidupannya dengan peradaban agung. Dengan kata lain, peradaban Islam dari waktu ke waktu merupakan perwujudan dari jihad. Dengan memaknai jihad semacam itu, kaum muslim menggapai puncak prestasi dalam pengembangan ilmu pengetahuan, sekaligus pembumiannya dalam kehidupan sepanjang sejarah yang dilalui. Namun dalam sejarah pula, jihad mengalami reduksi makna yang pada mulanya terkait erat dengan kondisi tertentu yang menuntut penekanan jihad pada bentuk pertahanan dan pembelaan diri. Hal ini berhubungan dengan keadaan pada masa pra-Islam, di mana wilayah Arab berada dalam state of war yang sebenarnya juga merupakan ciri umum dunia sebelum abad modern. ${ }^{28}$ Kondisi ini menyebabkan setiap komunitas harus terlibat dalam perang demi melindungi dan mempertahankan diri agar tidak diserang oleh kelompok lain. Ketika Islam datang, fenomena kehidupan seperti itu terus berlangsung dalam kehidupan umat. Maka, ketika Nabi saw. dan kaum Muslim hijrah ke Madinah, dan mereka diizinkan untuk melawan kaum musyrik, jihad dititikberatkan pada upaya

28 Abdul Hakim Sherman Jackson, "Jihad in the Modern World," The university of Michigan, 2015, ttps://lamppostedu.org/wpcontent/uploads/2011/01/JIHAD_MOD_WLD.pdf diakses 10 Januari 2018. 
mempertahankan diri dari ancaman dan serangan yang terus mereka hadapi.

Inilah titik awal kesalahan penafsiran tentang jihad yang pada gilirannya dijadikan sebagai alat justifikasi oleh sebagian penafsir untuk melakukan ekspresi radikalisme agama. Sebagaimana yang dipaparkan oleh al-Qardawi dalam bukunya as-Sahwah al-Islamiyyah Baina al-Jubud wa al-Tatarruf bahwa faktor utama munculnya sikap radikal dalam beragama adalah kurangnya pemahaman yang benar dan mendalam atas esensi ajaran agama Islam itu sendiri. Islam hanya dipahami secara dangkal dan parsial. $^{29}$

\section{Kesimpulan}

Munculnya Radikalisme disebabkan kesalahan dalam memahami ayat-ayat perang dan ayat-ayat Jihad. Pertama, ayat-ayat perang diartikan sebagai pembenaran bahwa aksi kekerasan dan terorisme dibenarkan dalam agama Islam. Kedua, ayat-ayat jihad diartikan sebagi perlawan terhdap segala musuh Islam adalah jihad. Padahal, radikalisme yang berujung pada tindakan kekerasan, bertentang dengan nilai-nilai dalam Agama. Hal ini bisa dilihat dari beberapa ayat Al-Qur'an berkaitan dengan peperangan atau jihad, dilihat dari asbabun nu₹ul tidak ada ayat yang menerangkan tentang kekerasan. Adapun ayat-ayat berkaitan dengan perintah jihad atau perang, berkaitan dengan adanya prinsip memepertahan diri dari serangan lawan, perjungan nilai-nilai kemanusian pada waktu itu.

\section{Daftar Pustaka}

A’la, Abd. "Pembumian Jihad Dalam Konteks Indonesia Kekinian: Pengentasan Masyarakat Dari Kemiskinan Dan Keterbelakangan." Harmoni 8, no. 32 (2009).

Al-Aqqad, Abbas Mahmud. Haqaiq Al-Islam Wa Abatil Khusumih. Kairo: Mu'assasah Hindawi, 2013.

Al-Qaradhawi, Yusuf. As-Sabwah Al-Islamiyyah Bayna Al-Jubud Wa at-Tatarruf. Kairo: Dar asy-Syuruq, 2001.

${ }^{29}$ Al-Qaradhawi, As-Sabwah Al-Islamiyyah Bayna Al-Jubud Wa at-Tatarruf, 67. 
Arkoun, Mohammed. Berbagai Pembacaan Al-Qur'an. Edited by Machasin. Jakarta: INIS, 1997.

Armstrong, Karen. Berperang Demi Tuban, Fundamentalisme Dalam Islam, Kristen Dan Yabudi. Jakarta: Serambi, 2001.

Azra, Azyumardi. Islam Reformis: Dinamika Intelektual Dan Gerakan. Jakarta: Raja Grafindo Persada, 1999.

Pergolakan Politik Islam. Bandung: Mizan, 1999.

Beuken, Wim, and Karl-Josef Kuschel. Agama Sebagai Sumber Kekerasan? Pustaka Pelajar, 2003.

Binder, Leonard. Islamic Liberalism; A Critique of Development Ideologies. Chicago and London: The University of Chicago Press, 1988.

Engineer, Asghar Ali. "Islam and Doctrines of Peace and NonViolence." Ibya 'Ulumuddin 3 (2001): 121.

Esposito, John L. Unholy War: Teror Atas Nama Islam. Yogyakarta: Ikon, 2003.

Halim, Muhammad Abdul. Menafsirkan Al-Qur'an Dengan Metode Menafsirkan Al-Qur'an Dengan Al-Qur'an,. Edited by Rofik Suhud. Bandung: Marja, 2012.

Hanafi, Muchlis M. "Konsep Al-Wasathiyyah Dalam Islam." Harmoni 8, no. 32 (2009).

Haryatmoko. Etika Politik Dan Kekuasaan. Jakarta: Kompas, 2003.

Hikam, Muhammad AS. Peran Masyarakat Sipil Indonesia Membendung Radikalisme. Jakarta: Kompas, 2016.

Hitti, Philip K. History of The Arabs. Tenth. London: The Macmilan Press LTD, 1974.

Jackson, Abdul Hakim Sherman. "Jihad in the Modern World." The university of Michigan, 2015. ttps://lamppostedu.org/wpcontent/uploads/2011/01/JIHAD_MOD_WLD.pdf.

Jumu'ah, Ali. Haqiqat Al-Islam Fi 'Alam Mutagayyir. Kairo: Kementerian Wakaf Mesir, 2003.

Kementerian Agama. Tafsir Al-Qur'an Tematik. Jakarta: Kamil 
Pustaka, 2014.

Kung, Hans, and Jurgen Moltmann. Fundamentalism as a Ecumanical Challenge. London: Mac Millan, 1992.

Qodir, Zuly. Radikalisme Agama Di Indonesia. Yogyakarta: Pustaka Pelajar, 2014.

Sirry, Mun’im A. Membendung Militansi Agama. Jakarta: Erlangga, 2003.

Sirry, Mun'in A. Membendung Militansi Agama: Iman Dan Politik Dalam Masyarakat Modern. Jakarta: Erlangga, 2003.

Susanto, Edi. "Kemungkinan Munculnya Paham Islam Radikal Di Pesantren." Tadris 2, no. 1 (2007).

Syalabi, A. Sejarah Dan Kebudayaan Islam. Jakarta: Pustaka al-Husna, 1994. 